Yoshitoshi, F. N.'; Migliani,M.2; Taboada, $\mathrm{P} .{ }^{3}$ confirmação do desvio, não foi autorizada pelos proprietários. Assim, as alterações clínicas, laboratoriais, ultra-sonográficas e histopatológicas permitem o diagnóstico de DMH, mas não excluem a possível associação com desvio porto-sistêmico macroscópico.

\section{2 - Estenose esofágica por Tricobezoar gástrico no cão. Relato de caso}

1- Serviço de Endoscopia Veterinária

2- Clinica Veterinária Faria Lima, São Paulo-SP

3- Serviço de Anatomia Patológica

As estenoses esofágicas são bandas de tecido fibroso intraluminal ou intramural que levam a obstrução total ou parcial do esôfago, podendo ser conseqüente a lesões por corpos estranhos, esofagites, ulceras, agentes cáusticos ou pelo refluxo e estase de suco gástrico na mucosa esofágica nos animais submetidos a anestesia geral. As estenoses mais comuns são aquelas ocasionadas pela lesão tecidual secundária ao corpo estranho em esôfago e são observados sinais de regurgitação a dietas sólidas e em caso de obstrução parcial, uma parte do bolo alimentar pode progredir para o estomago. Nào há predileção sexual e não são relacionados a idade $\mathrm{e}$ ao porte, podendo ocorrer tanto em cão quanto em gato. Foi atendido na clínica veterinária, um cão pincher , 4 anos, fêmea, com histórico de regurgitação há 4 meses. Ao exame clínico foi observado caquexia, mucosas perláceas e fraqueza muscular. Ao esofagograma, não houve progressão do contraste em terço posterior esofágico evidenciando dilatação em região anterior. Pela endoscopia foi confirmada a estenose esofágica em região próxima a cárdia, não permitindo progressão do tubo endoscópico para a cavidade gástrica. O proprietário ciente do prognóstico e custo do tratamento, optou pela eutanásia. Na necrópsia foi confirmado a dilatação esofágica, estenose em cárdia e encontrado na cavidade gástrica várias erosões em mucosa e também um tricobezoar. $\mathrm{A}$ presença do tricobezoar em cavidade gástrica, provavelmente deve ter levado o cão a mímica de vômito, causando um aumento de refluxo de suco gástrico na mucosa esofágica levando a um processo de esofagite e conseqüente estenose.

\section{3 - Reinfecção de cães por Babesia Canis: aspectos clínicos, hematológicos e imunidade humoral}

1- Pós-graduando do Departamento de Clínica Médica da Faculdade de Medicina Veterinária e Zootecnia da Universidade de São Paulo, São Paulo-SP

2- Professora Titular do Departamento de Clínica Médica da Faculdade de Medicina Veterinária e Zootecnia da Universidade de São Paulo, São Paulo-SP

A infecção por B. canis, hematozoário transmitido aos cães pelo carrapato Rhipicephallus sanguineus caracteriza-se, principalmente, pelo desenvolvimento de anemia hemolitica, de características regenerativas, esplenomegalia, trombocitopenia e febre intermitente. A icterícia pode ou não se desenvolver conseqüente à destruição intra ou extra vascular dos eritrócitos parasitados. A gravidade dos sintomas varia com a cepa de B. canis envolvida, idade e estado imune do hospedeiro. A infecção por Babesia sp, principalmente as cepas mais virulentas, resulta no estado de "pré-imunição" ou imunidade de presença, em que a infecção residual propicia ao hospedeiro imunidade contra as infecções subsequentes. Com o objetivo de avaliar a resistência dos cães à reinfecção, dez cães que haviam sido infectados com cepa local de B. canis, das quais a última infecção havia ocorrido há doze meses, receberam $5 \mathrm{~mL}$ de sangue parasitado por B. canis (cepa homóloga) por via I.V.. Temperatura corpórea, parasitemia, esplenomegalia, eritrograma, plaquetometria e título de anticorpos (IF) foram 